\title{
Human Rights and the Paris Agreement's Implementation Guidelines: Opportunities to Develop a Rights-based Approach
}

\author{
Sébastien Duyck, Erika Lennon, Wolfgang Obergassel, and Annalisa Savaresi*
}

The inclusion of references to human rights in the Paris Agreement was celebrated as a milestone towards greater integration of human rights in environmental and climate governance. Beyond their symbolic value, the significance of these provisions however depends on the extent to which they inform the implementation of the Paris Agreement both at the national and international levels. This article takes stock of the integration of human rights in climate governance and identifies concrete opportunities to ensure that human rights considerations are included in the Paris implementation guidelines to be adopted at the Conference of the Parties in Katowice in December 2018, promoting climate action that aligns with Parties' human rights obligations. We first consider the relevance of human rights to climate action and the incremental recognition of these linkages in the international climate regime - both in the lead up to the adoption of the Paris Agreement and since. We then consider in specific terms how human rights could inform five key dimensions of the Paris Agreement's implementation guidelines: guidance for nationally determined contributions, adaptation communications, transparency framework, global stocktake, and the Article 6 mechanisms. The article reflects on past experience of how climate policy impacts human rights and on proposals put forward in the context of the negotiations of the implementation guidelines, and concludes with recommendations on a rights-based approach to implementing the Paris Agreement.

\section{Introduction}

Climate change poses a significant threat to the realisation of human rights, and measures to address the impacts of climate change also risk producing perverse outcomes. ${ }^{1}$ The Paris Agreement, acknowledg-

DOI: $10.21552 / \mathrm{cclr} / 2018 / 3 / 5$

* Sébastien Duyck, Senior Attorney, Climate \& Energy, Center for International Environmental Law (CIEL); Affiliated Researcher, University of Lapland; Erika Lennon, Senior Attorney, Climate \& Energy, Center for International Environmental Law (CIEL); Wolfgang Obergassel, Project Co-ordinator, Wuppertal Institute; Annalisa Savaresi, Lecturer in Environmental Law, Stirling University. For correspondence: Sébastien Duyck <sduyck@ciel.org>, Erika Lennon <elennon@ciel.org>, Wolfgang Obergassel $<$ wolfgang.obergassel@wupperinst.org>, Annalisa Savaresi <annalisa.savaresi@stir.ac.uk>.

1 See eg United Nations Office of the High Commissioner for Human Rights, 'A New Climate Change Agreement Must Include Human Rights Protections for All' (17 October 2014) <https:// www.ohchr.org/Documents/HRBodies/SP/SP_To_UNFCCC.pdf> accessed 17 September 2018.

2 Paris Agreement (adopted 12 December 2015, entered into force 4 November 2016) 55 ILM 740 preamble. ing this intertwined reality, became the first international environmental treaty to explicitly reference human rights. Its preamble specifies that Parties 'should, when taking action to address climate change, respect, promote and consider their respective obligations on human rights', citing 'the right to health, the rights of indigenous peoples, local communities, migrants, children, persons with disabilities and people in vulnerable situations and the right to development, as well as gender equality, empowerment of women and intergenerational equity.' ${ }^{2}$ By forging an explicit link with human rights law, the Paris Agreement recalls and strengthens the expectation that Parties will take into account their existing human rights obligations concerning matters such as, for example, public participation or the rights of women and indigenous peoples when they design and implement climate change responses.

The references to human rights in the Paris Agreement are in many connections ground-breaking, and 
gravid with consequences for the interpretation of Parties' obligations. However, the significance of these references largely depends on how they ultimately inform the implementation of the Paris Agreement at the local, national, and international levels.

A robust set of implementation guidelines - resulting from a work programme initiated at the COP $21^{3}$ and to be adopted at the $24^{\text {th }}$ Conference of the Parties (COP) in Katowice in December $2018^{4}$ will be critical to ensure that the Paris Agreement contributes to mitigating the impacts of climate change on the enjoyment of human rights by present and future generations. A rights-based approach to the implementation of the Paris Agreement should therefore take into account the scale of climate change responses, informing Parties' level of ambition of both action and support.

Other contributions to this special issue address specific elements of the guidelines in greater detail. ${ }^{5}$ This article reflects specifically on the evolving relationship between climate change and human rights law, and how this has affected the development of the Paris Agreement's implementation guidelines. We explore how human rights can inform the Paris Agreement's implementation guidelines, drawing on lessons learned from past policies, proposals put forward by Parties and observers, and good practices from other United Nations (UN) processes.

\section{Setting the Stage: Human Rights and the Implementation of the Paris Climate Agreement}

Human rights are widely recognised in both international and national law as a set of basic rights and freedoms that belong to every person. ${ }^{6}$ Together, the corpus of human rights law provides substantive rights, such as the rights to life, food, water, the highest attainable level of health, and housing, as well as procedural rights, such as the rights to information and participation in environmental matters. ${ }^{7}$ While these international instruments were drafted at a time when climate change was either not understood or not perceived as an immediate threat, the rights provided in these legal instruments - as well as states' obligations associated with them - must be interpreted in light of current circumstances and in the context of climate change. All Parties to the climate regime have ratified at least one international human rights treaty. References to Parties' 'existing obligations' in the Paris Agreement should therefore be interpreted to refer to obligations in human rights treaties each Party has already ratified. ${ }^{8}$

Conversely, measures adopted to tackle climate change may themselves have (and indeed have already had) negative impacts on the enjoyment of human rights. ${ }^{9}$ This is especially the case for measures affecting access to, and the use of, natural resources, such as land, water, and forests, which can interfere
3 UNFCCC 'Decision 1/CP.21, Adoption of the Paris Agreement' UN Doc FCCC/CP/2015/10/Add.1 (29 January 2016) para 9.

4 UNFCCC, 'Decision 1/CP.22, Preparations for the Entry into Force of the Paris Agreement and the First Session of the Conference of the Parties Serving as the Meeting of the Parties to the Paris Agreement' UN Doc FCCC/CP/2016/10/Add.1 (31 January 2017) para 10.

5 See eg Christopher Campbell-Duruflé, 'Rain or Sunshine in Katowice? Transparency in the Paris Agreement Rulebook' (2018) 12 CCLR; Jennifer Huang, 'What Can the Paris Agreement's Global Stocktake Learn from the Sustainable Development Goals?' (2018) 12 CCLR (both in this issue).

6 The core international instruments include: Universal Declaration of Human Rights (adopted 10 December 1948 UNGA Res 217 A(III); International Covenant on Civil and Political Rights (adopted 16 December 1966, entered into force 23 March 1976) 999 UNTS 171; International Covenant on Economic, Social and Cultural Rights (adopted 16 December 1966, entered into force 3 January 1976) 993 UNTS 3. Additional specialised international instruments include: Convention on the Elimination of All Forms of Discrimination Against Women (adopted 18 December 1979, entered into force 3 September 1981) 1249 UNTS 13; Convention on the Rights of the Child (20 November 1989, entered into force 02 September 1990) 1577 UNTS 3 (20 November 1989). Finally, there are regional human rights treaties: African Charter on Human and Peoples' Rights (adopted 27 June 1981, entered into force 21 October 1986) (1982) 21 ILM 58; American Convention on Human Rights, (adopted 22 November 1969, entered into force 18 July 1978) 1144 UNTS 123; European Convention for the Protection of Human Rights and Fundamental Freedoms (4 November 1950, entered into force 3 September 1953) 2889 UNTS 221

7 Convention on Access to Information, Public Participation in Decision-Making and Access to Justice in Environmental Matters (adopted 25 June 1998, entered into force 30 October 2001) 2161 UNTS 447; Regional Agreement on Access to Information, Participation and Justice in Environmental Matters in Latin America and the Caribbean (adopted 4 March 2018, not yet in force) $<$ https://repositorio.cepal.org/bitstream/handle/ 11362/43583/1/S1800428_en.pdf> accessed 15 September 2018.

8 Annalisa Savaresi, 'Climate Change and Human Rights: Fragmentation, Interplay and Institutional Linkages' in Sébastien Duyck, Sébastien Jodoin, and Alyssa Johl (eds), Routledge Handbook of Human Rights and Climate Governance (Routledge 2018) 31 32

$9 \mathrm{OHCHR}$ 'Report on the Relationship between Climate Change and Human Rights' UN Doc A/HRC/10/61 (2009) 65-68. 
with the enjoyment of human rights, such as that to food, culture, the respect for family life, access to safe drinking water and sanitation, and indigenous peoples' self-determination. ${ }^{10}$

The complex relationship between climate change and human rights obligations has increasingly been recognised in the literature, ${ }^{11}$ by the Parties to the climate regime, ${ }^{12}$ and by human rights bodies. ${ }^{13} \mathrm{~A}$ string of Human Rights Council (HRC) resolutions emphasises the potential of states' existing human rights obligations to 'inform and strengthen' climate change law- and policy-making, by 'promoting policy coherence, legitimacy and sustainable outcomes.. ${ }^{14}$ The HRC has also called upon states to integrate human rights in their climate actions. ${ }^{15}$ When applied to the context of climate change, states' human rights obligations may be summarised as follows:

(i) Mitigation: States must act to limit anthropogenic emissions of greenhouse gases and protect natural carbon sinks, including through regulatory measures, in order to prevent, to the greatest extent possible, the current and future negative human rights impacts of climate change;

(ii) Adaptation: States must ensure that appropriate adaptation measures are taken to protect and fulfil the rights of all persons, particularly those most endangered by the negative impacts of climate change such as those living in vulnerable areas;

$10 \mathrm{OHCHR}$ 'Report of the Special Rapporteur on the Issue of Human Rights Obligations Relating to the Enjoyment of a Safe, Clean, Healthy and Sustainable Environment' UN Doc A/HRC/31/52 (2016) 50-64.

11 See eg Stephen Humphreys (ed), Human Rights and Climate Change (Cambridge University Press 2009); 'Symposium: International Human Rights and Climate Change' (2010) 38 Georgia J Intl \& Comp L; Lavanya Rajamani, 'The Increasing Currency and Relevance of Rights-Based Perspectives in the International Negotiations on Climate Change', (2010) 22 JEL 391; Siobhán Mclnerney-Lankford, Mac Darrow and Lavanya Rajamani, Human Rights and Climate Change: A Review of the International Legal Dimensions (World Bank 2011); Ottavio Quirico and Mouloud Boumghar (eds), Climate Change and Human Rights: An International and Comparative Law Perspective (Routledge 2015); Sébastien Duyck, Sébastien Jodoin and Alyssa Johl (eds), Routledge Handbook of Human Rights and Climate Governance (Routledge 2018).

12 The Mary Robinson Foundation - Climate Justice, 'Incorporating Human Rights into Climate Action' (May 2016) <https://www mrfcj.org/wp-content/uploads/2016/05/Incorporating-Human -Rights-into-Climate-Action-Version-2-May-2016.pdf $>$ accessed 15 September 2018.

13 See eg Solicitada por la República de Colombia, Medio Ambiente y Derechos Humanos, Opinión Consultiva [2017] OC-23/17 IACtHR para 47 (consultative opinion 2017), <http://www .corteidh.or.cr/docs/opiniones/seriea_23_esp.pdf > accessed 15 September 2018. For a compendium, see Center for International (iii) Accountability and remedies: States must guarantee effective remedies for human rights violations;

(iv) Regulation of business activities: States must take adequate measures to protect all persons from human rights harms caused by business activities and, where such harms do occur, provide effective remedies;

(v) International cooperation: States must participate in international negotiations and ensure that mitigation and adaptation activities do not themselves contribute to human rights violations. ${ }^{16}$

Human rights law leaves states some discretion in striking a balance between the pursuit of climate change mitigation and adaptation and other legitimate societal interests. As noted by former UN Special Rapporteur on Human Rights and the Environment John Knox, however, this balance may not be 'unjustifiable or unreasonable'. ${ }^{17}$ Furthermore, states owe heightened obligations to members of groups in vulnerable situations or who are particularly vulnerable to harm. ${ }^{18}$

Well ahead of the adoption of the Paris Agreement, UN Framework Convention on Climate Change (UNFCCC) Parties took heed of the linkages between human rights and climate change law obligations. In 2010, the Cancun Agreements noted that 'adverse effects of climate change have a range of direct and indirect implications for the effective enjoyment of hu-

Environmental Law (CIEL) and Global Initiative for Economic, Social and Cultural Rights (GIESCR), 'State Human Rights Obligations in the Context of Climate Change: Synthesis Note on the Concluding Observations and Recommendations on Climate Change Adopted by UN Human Rights Treaty Bodies' (January 2018) <http://www.ciel.org/wp-content/uploads/2018/01/HRTBs -synthesis-report.pdf> accessed 15 September 2018.

14 See HRC 'Res 7/23, Human Rights and Climate Change' UN Doc A/HRC/Res/7/23 (2008); HRC 'Res 10/4, Human Rights and Climate Change' UN Doc A/HRC/Res/10/4 (2009); HRC 'Res 18/22, Human Rights and Climate Change' UN Doc A/HRC/Res/18/22 (2011); HRC 'Res 26/27, Human Rights and Climate Change' UN Doc A/HRC/Res/26/27 (2014); HRC 'Res 29/15, Human Rights and Climate Change' UN Doc A/HRC/Res/29/15 (2015); HRC 'Res 32/33, Human Rights and Climate Change' UN Doc A/HRC/RES/32/33 (2016); HRC 'Res $34 / 20$, Human Rights and the Environment' UN Doc $\mathrm{A} / \mathrm{HRC} / 34 / 20$ (2017).

$15 \operatorname{Res} 32 / 33$ (n 14) para 9; Res 34/20 (n 14) para 5.

$16 \mathrm{OHCHR}$, 'Understanding Human Rights and Climate Change' (2015) 3 .

$17 \mathrm{OHCHR}$ 'Report of the Special Rapporteur on the Issue of Human Rights Obligations Relating to the Enjoyment of a Safe, Clean, Healthy and Sustainable Environment' UN Doc A/HRC/37/59 (2018) para 33(e)

18 ibid para 3, principles 14-15 
man rights'19 and acknowledged that Parties 'should, in all climate change related actions, fully respect human rights'. ${ }^{20}$ The functioning of the Clean Development Mechanism (CDM), ${ }^{21}$ REDD+, ${ }^{22}$ and the disbursement of climate finance ${ }^{23}$ confronted states and international agencies with challenging questions over the interplay between climate change and human rights law obligations. The need to ensure compatibility between climate action and the protection of human rights has been progressively emphasised $^{24}$ and included in standards adopted by some climate finance institutions. ${ }^{25}$

Numerous textual suggestions for references to human rights were made during the negotiations of the Paris Agreement. ${ }^{26}$ The reference to human rights eventually included in the preamble does not create new and separate legal obligations for Parties, but merely draws attention to obligations they already have undertaken under the human rights treaties they ratified, or may ratify in future, and to relevant customary norms and domestic laws. ${ }^{27}$ Further, the operative part of the treaty makes reference to genderresponsiveness, the importance of traditional knowledge, and the need for further cooperation related to public participation and access to information. ${ }^{28}$

The Paris Agreement thus breaks new ground, with significant implications for the implementation and further development of Parties' obligations un-

19 UNFCCC 'Decision 1/CP.16, The Cancun Agreements: Outcome of the work of the Ad Hoc Working Group on Long-term Cooperative Action under the Convention' UN Doc FCCC/CP/2010/7/Add.1 (15 March 2011) preamble, recital 7.

20 ibid para 8; see Sébastien Duyck, Sébastien Jodoin, and Alyssa Johl, 'Integrating Human Rights in Climate Governance: An Introduction' in Duyck et al (n 11) 3.

21 See eg Lambert Schneider, 'Is the CDM Fulfilling Its Environmental and Sustainable Development Objectives? An Evaluation of the CDM and Options for Improvement' (Öko-Institut 2007); Christof Arens, Hanna Wang-Helmreich and Timon Wehnert, 'Mitigation versus Sustainable Development? Why NAMAs Shouldn't Repeat the CDM's Mistakes' (2011) 17 Joint Implementation Quarterly 6; Lena Ruthner et al, 'Study on the Integrity of the Clean Development Mechanism (CDM)' (AEA 2011); Wolfgang Obergassel et al., 'Human Rights and the Clean Development Mechanism: Lessons Learned from Three Case Studies' (2017) 8 JHRE 51.

22 See Annalisa Savaresi, 'The Human Rights Dimension of REDD', (2012) 21 RECIEL 102; Annalisa Savaresi, 'REDD+ and Human Rights: Addressing Synergies Between International Regimes', (2013) 18 Ecology \& Society 5; Annalisa Savaresi, 'The Role of REDD in Harmonising Overlapping International Obligations' in Erkki Hollo, Kati Kulovesi and Michael Mehling (eds), Climate Change and the Law (Springer 2013) 391.

23 See Alyssa Johl and Yves Lador, 'A Human-Rights Based Approach to Climate Finance' (FES 2012), <http://library.fes.de/pdf -files/iez/global/08933.pdf> accessed 15 September 2018; Damilola S Olawuyi, The Human Rights-Based Approach to Carbon Finance (Cambridge University Press 2016). der the climate regime, which are already evident in the context of the newly established Local Communities and Indigenous Peoples Platform, ${ }^{29}$ the Paris Committee on Capacity-building, ${ }^{30}$ the Gender Action Plan, ${ }^{31}$ and the Talanoa Dialogue. ${ }^{32}$ The remainder of this article analyses how the relationship with human rights obligations is being addressed in the context of the on-going development of the Paris Agreement implementation guidelines.

\section{Human Rights in the Paris Agreement Implementation Guidelines}

While the Paris Agreement lays out the main framework for future international cooperation on climate action, it does not provide detailed guidance on the design of national climate plans or the operationalisation of the review and reporting processes it envisions. Consequently, when adopting the Paris Agreement, the contracting Parties also established a process to negotiate a set of 'implementation guidelines'. The task of negotiating these guidelines was primarily attributed to a new subsidiary body established for this purpose - the Ad-hoc Working Group on the Paris Agreement (APA) - with other subsidiary bodies also addressing discrete aspects of the guidelines. The outcome of these negotiations is 'essential

24 Decision 1/CP.16 (n 19) Appendix I, para 2(a).

25 See eg Adaptation Fund, 'Environmental and Social Policy' (2016) 15; Green Climate Fund, 'Environmental and Social Policy', GCF/B.19/10 (March 2018) <https://www.greenclimate.fund/ documents/20182/574763/GCF_policy__Environmental_and _Social_Policy.pdf/aa092a12-2775-4813-a009-6e6564bad87c> accessed 15 September 2018; Green Climate Fund, 'Indigenous Peoples' Policy', GCF/B.19/11 (March 2018) <https://www greenclimate.fund/documents/20182/574763/GCF_policy _-_Indigenous_Peoples_Policy.pdf/6af04791-f88e-4c8a-8115 -32315a3e4042> accessed 15 September 2018.

26 See Annalisa Savaresi and Jacques Hartmann, 'Human Rights in

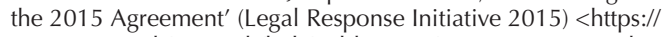
www.stir.ac.uk/research/hub/publication/552778> accessed 15 September 2018.

27 Savaresi, 'Climate Change and Human Rights' (n 8) 32.

28 Paris Agreement (n 2) arts 7(5), 11(2), and 12.

29 Decision 1/CP.21 (n 3) paras 135-136; UNFCCC 'Report of the Conference of the Parties on its Twenty-second Session, Held in Marrakech from 7 to 18 November $2016^{\prime}$ UN Doc FCCC/CP/2016/10 (31 January 2017) paras 163-167.

30 Decision 1/CP.21 (n 3) para 71.

31 UNFCCC 'Decision 3/CP.23, Establishment of a Gender Action Plan' UN Doc FCCC/CP/2017/11/Add.1 (8 February 2018).

32 UNFCCC 'Decision 1/CP.23, Fiji Momentum for Implementation' UN Doc FCCC/CP/2017/11/Add.1 (8 February 2018) paras 10-11, and Annex II. 
to operationalise national and international commitments to combat intensifying climate change in a fair and effective manner. ${ }^{33}$

The international climate change governance architecture established by the Paris Agreement has been described as 'hybrid' in that it combines an international system of rules to review the implementation, compliance, and effectiveness of Parties' action. ${ }^{34}$ In this context, the guidelines are expected to provide details on designing national plans on mitigation, adaptation, and provision of support, as well as on procedures and modalities for the review of implementation, compliance, and effectiveness. ${ }^{35}$ The guidelines therefore will significantly inform the operationalisation of the Paris Agreement. Several countries, institutions, and stakeholders have sought to ensure that the human rights language contained in the treaty's preamble is reflected in the guidelines. ${ }^{36}$ This section explores the elements of the implementation guidelines that could further integrate human rights considerations in the operationalisation of the Paris Agreement.

\section{Further Guidance in Relation to Nationally Determined Contributions}

The nationally determined contributions (NDCs) that all Parties are under the legal obligation to prepare, communicate, and maintain on the basis of successive five-year cycles are the central feature of the Paris

33 Yamide Dagnet et al, 'Setting the Paris Agreement in Motion: Key Requirements for the Implementing Guidelines' (2018) Project for Advancing Climate Transparency (PACT) $2<$ https://www.wri.org/ publication/pact-implementing-guidelines $>$.

34 Lavanya Rajamani, 'Ambition and Differentiation in the 2015 Paris Agreement: Interpretative possibilities and underlying politics' (2016) 65 ICLQ 493; Daniel Bodansky, Jutta Brunnée and Lavanya Rajamani, International Climate Change Law (Oxford University Press 2017) 217.

35 Annalisa Savaresi 'The Paris Agreement: Reflections on an International Law Odyssey' in Ineta Ziemele and Georg Ulrich (eds), How International Law Works in Times of Crisis? (Oxford University Press 2018, fc).

36 Christel Cournil and Camila Perruso, 'Réflexions sur "I'Humanisation" des Changements Climatiques et la "Climatisation" des Droits de l'Homme. Émergence et Pertinence' (2018) 14 La Revue des Droits de I'Homme 24.

37 Paris Agreement (n 2) arts 4(2)-4(9).

38 See eg Daniel Bodansky, 'The Legal Character of the Paris Agreement' (2016) 25 RECIEL 142, 145; Annalisa Savaresi, 'The Paris Agreement: A New Beginning?' (2016) 34 J Energy \& Natural Resources L 16, 21.

39 Paris Agreement (n 2) art 4(2)
Agreement. ${ }^{37}$ Parties' obligations concerning NDCs are largely obligations of conduct, rather than of results, ${ }^{38}$ meaning that states must submit NDCs and pursue measures to achieve them. ${ }^{39}$

The NDCs submitted by Parties thus far differ widely in scope and nature. Developed countries' NDCs primarily consist of quantified emission reductions targets similar to those submitted under the Kyoto Protocol, while most developing countries' NDCs, instead, also address adaptation, capacity, and finance needs. Many NDCs include information regarding the human and social dimensions of the implementation of climate response measures, or their linkages with broader goals associated with sustainable development. ${ }^{40}$ Seventeen Parties have committed to implement their response measures in a rights-based manner, ${ }^{41}$ while another seven mentioned human rights as elements of the legal framework providing the context for the implementation of the contribution. ${ }^{42}$ In addition, many NDCs refer to concepts closely related to human rights, such as public participation, food security, gender equality or the participation of women, and indigenous peoples and traditional knowledge. ${ }^{43}$ Several Parties therefore do recognise, explicitly or implicitly, the link between climate action and the protection of human rights in their NDCs.

During the negotiations of the Paris Agreement, several actors sought to limit Parties' discretion in the drafting of their NDCs. ${ }^{44}$ Ultimately, the Agreement requires Parties to prepare NDCs in accordance with guidance to be developed by the COP serving as the

40 Eliza Northrop et al, 'Examining the Alignment between the Intended Nationally Determined Contributions and Sustainable Development Goals' (World Resources Institute 2016) <https:// www.wri.org/sites/default/files/WRI_INDCs_v5.pdf>.

41 Bolivia, Brazil, Chad, Chile, Costa Rica, Ecuador, Georgia, Guatemala, Guyana, Honduras, Malawi, Marshall Islands, Mexico, Morocco, Philippines, South Sudan, and Uganda.

42 Cuba, El Salvador, Indonesia, Nepal, Venezuela, Yemen, and Zimbabwe

43 Authors have mapped the original intended NDCs (INDCs) submitted by Parties for references to various principles. The importance of public participation in the implementation of climate commitments is explicitly stated in 71 INDCs. Additionally, 97 INDCs refer to the importance of food production or food security, 56 INDCs refer to gender aspects or the participation and empowerment of women, and 19 INDCs include references to indigenous peoples or traditional knowledge. More information can be found on <https://www.climaterights.org >. On the gender dimension of NDCs, see also Paul Tobin, Nicole M Schmidt, Jale Tosun, and Charlotte Burns, 'Mapping States' Paris Climate Pledges: Analysing Targets and Groups at COP 21' (2018) 48 Global Environmental Change 11.

44 Rajamani, 'Ambition and Differentiation in the 2015 Paris Agreement' (n 34) 500 . 
Meeting of the Parties to the Paris Agreement (CMA). ${ }^{45}$ Since 2016, these negotiations have taken place under the auspices of the APA, and have been structured around three issues: the features of NDCs (their scope); the information to facilitate clarity, transparency, and understanding (ICTU); and accounting for NDCs.

The ICTU negotiations provide the most promising avenue to develop a human rights-based approach to NDCs. Parties have agreed that they may provide information related to their NDC planning process. ${ }^{46}$ Some Parties have suggested that this could include information related to human rights, stakeholder consultations, indigenous peoples and local communities, elders and youth, just transition, and gender. ${ }^{47}$ More specifically, these Parties have suggested adopting non-mandatory guidance enabling Parties to 'opt-in', by providing relevant information in their NDCs. This approach could create a virtuous cycle, allowing Parties to share information related to the preparation of their second NDC (i.e. 2019-2020), with more countries potentially following suit in subsequent cycles. The provision of information would also allow Parties to reflect on their domestic experience regarding rights-based and participatory climate decision-making, thereby enabling others to benefit from lessons learned.

This proposal is included in the 'additional tool', prepared by the APA co-chairs in August 2018 as a basis for future negotiations. ${ }^{48}$ The draft guidelines could be further strengthened by differentiating more explicitly the invitation for Parties to provide information on procedural aspects related to the planning of NDCs (i.e. how stakeholders have participated throughout the preparatory process) and to the substance of NDCs (i.e. how considerations related to human rights and related principles will be reflected in the implementation of NDCs). Also, the invitation to provide information related to the integration of human rights considerations in the planning of NDCs should refer not only to human rights, but build on the language used in the preamble of the Paris Agreement, and refer to the rights of indigenous peoples, gender equality, food security, just transition, and the importance of traditional knowledge.

\section{Adaptation Communications}

Adaptation communications are the second entry point for developing a rights-based approach to the implementation of the Paris Agreement. The Paris Agreement provides that Parties 'should, as appropriate, submit and update periodically an adaptation communication, which may include its priorities, implementation and support needs, plans and actions' ${ }^{49}$ The Agreement specifies that adaptation communications may be part of existing reporting processes under the climate regime, such as NDCs, national communications, and developing countries' national adaptation plans. ${ }^{50}$

The guidance for adaptation communications under negotiation by the APA at the time of drafting could provide a means for Parties to identify, monitor, and share their experiences with regards to rightsbased climate adaptation measures and policies. This approach would contribute to fulfilling the Paris Agreement's vision that adaptation action should follow 'a country-driven, gender-responsive, participatory and fully transparent approach, taking into consideration vulnerable groups, communities and ecosystems', based on and guided by, among others, 'traditional knowledge, knowledge of indigenous peoples and local knowledge systems. ${ }^{51}$

Former UN Special Rapporteur John Knox has noted that, even though rights-based adaptation measures will vary from situation to situation, states must nevertheless comply with relevant national and international standards. ${ }^{52}$ These standards include those defined under the Sendai Framework, ${ }^{53}$ as well as relevant human rights instruments, such as the

\footnotetext{
45 Paris Agreement (n 2) art 4(8).

46 Decision 1/CP.21 (n 3) para 27.

47 See the original proposal in 'Norway's Submission on Features, Information to Facilitate Clarity, Transparency and Understanding and Accounting of Parties' Nationally Determined Contributions' (September 2017) 6 <http://www4.unfccc.int/Submissions/Lists/ OSPSubmissionUpload/854_356_131501386398003119-APA $\% 203$ Norway.pdf $>$ accessed 15 September 2018. Canada and the European Union have expressed support for this proposal.

48 See eg 'Further Guidance in Relation to the Mitigation Section of Decision 1/CP.21 on: (a) Features of Nationally Determined Contributions, as Specified in Paragraph 26; (b) Information to Facilitate Clarity, Transparency and Understanding of Nationally Determined Contributions, as Specified in Paragraph 28; and (c) Accounting for Parties' Nationally Determined Contributions, as Specified in Paragraph 31', APA1.6.Informal.1.Add.1 (6 August 2018) 9, 11. 
Convention on the Elimination of All Forms of Discrimination Against Women. ${ }^{54}$ By focusing on the personal condition of individuals exposed, a human rights approach can inform adaptation policies to better protect those most at risk, instead of focusing on aggregate assessments of economic interests. ${ }^{55} \mathrm{Ad}-$ ditionally, human rights frameworks can contribute to enhance adaptation planning by clarifying the legal duty of branches of the government to protect their citizens and thereby enhance the accountability of decision-makers. ${ }^{56}$

Some Parties' NDCs already identify human rights, gender equality, just transition, and local and indigenous knowledge as factors to prioritise in adaptation action. ${ }^{57}$ Several Parties have furthermore suggested that the guidelines on adaptation communications include references to a gender-sensitive and participatory approach, relying on indigenous peoples' and traditional knowledge. ${ }^{58}$ The 'additional tool' produced by the APA co-chairs in August 2018 includes references to this language, for instance in relation to 'adaptation priorities, plans, strategies, planned actions', and to the monitoring and evaluation of adaptation action. ${ }^{59}$ These suggestions, however, fall short of requesting that Parties provide information on rights-based approaches to adaptation. To date, international cooperation under the UNFCCC and support provided by the various bodies established under the Convention have largely failed to adopt a rightsbased approach to adaptation. ${ }^{60}$

The guidelines for adaptation communications offer an opportunity for Parties to change course, learn from earlier shortcomings, and provide greater sup- port for rights-based adaptation. The guidelines on the preparation of adaptation communications could invite Parties to submit information concerning specifically rights-based approaches to adaptation, both in the context of planning and priorities, and of the monitoring of measures taken. ${ }^{61}$

\section{Transparency Framework}

The successful implementation of the Paris Agreement will depend to a large extent on Parties' ability to review individual and collective progress towards achieving the treaty's objectives. ${ }^{62}$ The transparency framework envisioned under Article 13 is a crucial means to this end.

The success of this model will depend to a significant extent on whether the review will solely consider information concerning greenhouse gas emissions, or whether it will also consider whether climate policies are implemented in line with other societal objectives and existing legal frameworks. ${ }^{63}$ The Paris Agreement's references to human rights seem to suggest that to get a 'clear understanding of climate change action, ${ }^{\prime}{ }^{64}$ the transparency framework should include information on good practices, including rights-based approaches to mitigation and adaptation action, as well as support.

Existing UNFCCC guidelines on the reporting of climate action already invite Parties to submit information on issues of direct relevance to the protection of human rights, such as legal frameworks applicable to climate action, the impacts of climate change

54 Committee on the Elimination of Discrimination against Women 'General Recommendation No. 37 on Gender-related Dimensions of Disaster Risk Reduction in the Context of Climate Change' UN Doc CEDAW/C/GC/37 (2018)

55 See eg John C Mutter and Kye Mesa Barnard, 'Climate Change, Evolution of Disasters and Inequality' in Stephen Humphreys (n 11) 272 .

56 See lan Christoplos, Mikkel Funder, Colleen McGinn and Winnie Wairimu, 'The Role of Human Rights in Climate Change Adaptation: Evidence from civil society in Cambodia and Kenya' (17 December 2014) 3 <https://www.diis.dk/en/research/human -rights-based-approaches-can-protect-people-vulnerable-to -climate-change> accessed 15 September 2018

57 UNFCCC, 'Technical Paper: Adaptation-Related Information Included in Nationally Determined Contributions, National Adaptation Plans and Recent National Communications' UN Doc FCCC/TP/2017/7 (2 October 2017).

58 These Parties included Australia, the Independent Association of Latin America and the Caribbean (AILAC), Norway, Canada, and the Least Developed Countries, with the African Group of Nego-

tiators making a similar proposal focused on addressing only the gender dimension.

59 APA Co-chairs, 'Additional Tool under Item 4 of the Agenda: Further Guidance in Relation to the Adaptation Communication Including, inter alia, as a Component of Nationally Determined Contributions, Referred to in Article 7, Paragraphs 10 and 11, of the Paris Agreement', APA1.6.Informal.1.Add.2 (2 August 2018).

60 See eg Sven Harmeling 'Climate Change Impacts: Human Rights in Climate Adaptation and Loss and Damage' in Duyck et al ( $\mathrm{n}$ 11) 104 .

61 APA Co-chairs, 'Additional Tool under Item 4 of the Agenda' (n 59) $13,16$.

62 Charlotte Streck, Paul Keenlyside, and Moritz von Unger, 'The Paris Agreement: A New Beginning' (2016) 13 J Eur Envtl \& Planning L 3, 21.

63 For example, Parties' human rights obligations under the core human rights instruments referenced above (n 6).

64 Paris Agreement (n 2) art 13(5). 
on health and food security, ${ }^{65}$ as well as the promotion of public participation and access to information. ${ }^{66}$ These guidelines, however, do not ask Parties to submit information specifically concerning the integration of human rights in climate action. ${ }^{67} \mathrm{How}$ ever, several Parties have included references to human rights in their latest national communications under the UNFCCC. ${ }^{68}$ Nevertheless, most of these references do not clearly indicate the steps adopted to incorporate human rights considerations into climate action. So far, only two states - Belgium and Luxemburg - have included a sub-section dedicated to human rights and gender in the context of their domestic climate action. ${ }^{69}$ Ecuador's national communication also provides detailed information on the relevance of human rights to domestic climate action throughout the document. ${ }^{70}$ Other countries mention human rights in their national communications in relation either to general statements of principles or to address only one discrete aspect of climate policies.

Beyond the UNFCCC, states already report information concerning climate action under various human rights processes, including the HRC's Universal Periodic Review, the reporting procedures of human rights treaty bodies, and the voluntary national reviews conducted by the High-Level Political Forum. As such, many states already provide information concerning the interlinkages between human rights and climate impacts or policies through one or several of these forums. ${ }^{71}$ However, at the time of draft-

65 Sébastien Duyck, 'Respecting Human Rights in Climate Action, An Assessment of Countries' Policies through a Review of National Reports' (2015) (report commissioned by the Mary Robinson Foundation for Climate Justice, on file with authors).

66 UNFCCC 'Decision 15/CP.18, Doha Work Programme on Article 6 of the Convention' UN Doc FCCC/CP/2012/8/Add.2 (28 February 2013) Annex, para 31.

67 See UNFCCC 'Decision 3/CP.1, Preparation and Submission of National Communications from the Parties Included in Annex I to the Convention' UN Doc FCCC/CP/1995/7/Add.1 (6 June 1995); UNFCCC 'Decision 10/CP.2, Communications from Parties not Included in Annex I to the Convention: Guidelines, Facilitation and Process for Consideration' UN Doc FCCC/CP/1996/15/Add. 1 (29 October 1996); UNFCCC 'Decision 4/CP.5, Guidelines for the Preparation of National Communications by Parties Included in Annex I to the Convention, Part II: UNFCCC Reporting Guidelines on National Communications' UN Doc FCCC/CP/1999/6/Add.1 (17 January 2000) 8.

68 See a mapping of these references at 'Incorporating Human Rights into Climate Action' <https://www.mrfcj.org/incorporating-human -rights-into-climate-action/> accessed 15 September 2018.

69 See Belgium, '7th National Communication to the UNFCCC' (2017) 58; Luxemburg, '7th National Communication to the UNFCCC' (2017) 212. ing, there is little coherence between the information states submit under the climate regime and under human rights mechanisms. ${ }^{72}$ It would therefore be desirable to strengthen synergies across climate and human rights reporting obligations, promoting co- $^{-}$ herence while avoiding additional reporting burdens. $^{73}$

The guidelines on the transparency framework should ask Parties to provide information concerning how human rights are mainstreamed in the implementation of the Paris Agreement. Such information could be included in the sections of the reporting guidelines related to national circumstances and institutional arrangements, mitigation co-benefits, climate impacts and adaptation measures, and means of implementation provided and received. Furthermore, expert bodies such as the Least Developed Countries Expert Group or the Adaptation Committee could elaborate additional guidance to ensure that Parties' reporting is meaningful and fosters synergies with relevant international processes.

Finally, civil society actors should be involved in the Paris Agreement's transparency framework to enable the consideration of independent information about Parties' action. ${ }^{74}$ Reporting mechanisms established under other multilateral environmental agreements already give similar roles to civil society actors, as do international human rights mechanisms. ${ }^{75}$ The Paris Agreement implementation guidelines should replicate these practices, taking on board the proposals put forward by various states about this. ${ }^{76}$

70 Ecuador, '3rd National Communication to the UNFCCC' (2017) $69,219,468$

71 For a study of references to climate change in states' reports submitted to the Universal Periodic Review, see Edward Cameron and Marc Limon, 'Restoring the Climate by Realizing Rights: The Role of the International Human Rights System' (2012) 21 RECIEL 204. For an overview of the references to climate change in the States reports submitted to the Human Rights Treaty Bodies, see CIEL and GIESCR (n 13) Figure 2.

72 The Mary Robinson Foundation - Climate Justice (n 12) 11.

73 As also suggested in Savaresi, 'Climate Change and Human Rights' (n 8) 37

74 Harro van Asselt, 'The Role of Non-State Actors in Reviewing Ambition, Implementation, and Compliance under the Paris Agreement' (2016) 6 Climate L 91.

75 Sébastien Duyck, 'MRV in the 2015 Climate Agreement: Promoting Compliance through Transparency and the Participation of NGOs' (2014) CCLR 175

76 See APA Co-Chairs, 'Additional Tool under item 5 of the Agenda: Modalities, Procedures and Guidelines for the Transparency Framework for Action and Support Referred to in Article 13 of the Paris Agreement', APA1.6.Informal.1.Add.3 (3 August 2018) $71-72$. 


\section{Global Stocktake}

The Paris Agreement envisions a process to carry out a review of collective progress towards the implementation of the Agreement every five years, in light of the principle of equity and on the best available science. The outcome of this 'global stocktake' is meant to inform Parties in updating and enhancing their 'actions and support'. ${ }^{77}$ This process is crucial to ensuring that the bottom-up architecture envisioned in the Paris Agreement will deliver the results it was designed to produce. ${ }^{78}$

Article 14 explicitly provides that the global stocktake should be conducted in a comprehensive and facilitative manner. To deliver on this mandate, the review of collective progress must therefore consider all dimensions provided in the Paris Agreement, including the crosscutting principles listed in its preamble - such as human rights, the rights of indigenous peoples, and gender equality - and in Article 2 - sustainable development and the eradication of poverty. ${ }^{79}$ Consequently, the global stocktake should review climate action not only from a quantitative but also a qualitative perspective. Such a review would help identify good practices and barriers to implementation, and inform future NDCs and international cooperation.

The Subsidiary Body for Implementation has suggested that Parties may address issues related to cli-

77 Paris Agreement (n 2) art 14 (3).

78 Annalisa Savaresi 'The Paris Agreement: Reflections on an International Law Odyssey' in Ineta Ziemele and Georg Ulrich (eds), How International Law Works in Times of Crisis? (Oxford University Press 2018,fc) 15. See also Wolfgang Obergassel et al, 'Phoenix from the Ashes: An Analysis of the Paris Agreement to the United Nations Framework Convention on Climate Change, Part I' (2015) 27 Envtl L \& Management 243; Wolfgang Obergassel et al, 'Phoenix from the Ashes: An Analysis of the Paris Agreement to the United Nations Framework Convention on Climate Change, Part II' (2016) 28 Envtl L \& Management 3.

79 Paris Agreement (n 2) preamble, art 2.

80 UNFCCC 'Draft decision -/CMA.1, Ways of Enhancing the Implementation of Education, Training, Public Awareness, Public Participation and Public Access to Information so as to Enhance Actions under the Paris Agreement' UN Doc FCCC/SBI/2018/L.3/Add.2 (2018) para 9

81 APA Co-Chairs, 'Additional Tool under Item 6 of the Agenda: Matters Relating to the Global Stocktake Referred to in Article 14 of the Paris Agreement: (a) Identification of the Sources of Input for the Global Stocktake; and (b) Development of the Modalities of the Global Stocktake', APA1.6.Informal.1.Add.4 (2 August 2018) para 63

82 ibid paras 13, 29, 42, and 49

83 Paris Agreement (n 2) art 6(1)

84 Decision 1/CP.21 (n 3) para 38. mate education, public participation, and access to information in the context of the global stocktake. ${ }^{80}$ During APA negotiations on guidance for the global stocktake, several developing countries have stressed the need to consider, among other issues, 'efforts to eradicate poverty, food security, job creation, and social justice in developing countries, climate refugees and displaced people'. ${ }^{81}$ Equally, several Parties have insisted that the process should be as inclusive as possible by allowing for the participation of non-Party stakeholders. These proposals are reflected in the cochairs' August 2018 'additional tool. ${ }^{82}$ Importantly, including these considerations should not overshadow the significance for the global stocktake to address equity as mandated explicitly in the Paris Agreement.

As the stocktake is expected to play a leading role in framing climate action and inform the development of future NDCs, ensuring that this process increases awareness of rights-based solutions will be crucial. Inclusion of these proposals in the implementation guidelines would therefore turn the global stocktake into an opportunity to promote policy coherence and cooperation with other intergovernmental organisations whose mandate and expertise overlap with that of the climate regime. A participatory approach would furthermore promote rights-based climate action also in the context of international organisations outside of the UNFCCC by encouraging these organisations to develop knowledge products and operational tools that can feed into the global stocktake.

\section{Article 6 Mechanism}

Article 6 of the Paris Agreement provides several options for Parties to cooperate in achieving their NDCs, including through internationally transferred mitigation outcomes and a proposed mechanism. Such cooperation is supposed 'to allow for higher ambition in their mitigation and adaptation actions and to promote sustainable development and environmental integrity'. ${ }^{83}$ Article 6(4) establishes a new 'mechanism to contribute to the mitigation of greenhouse gas emissions and support sustainable development' (the socalled Sustainable Development Mechanism (SDM)), to be developed on the basis of, inter alia, "[e]xperience gained with and lessons learned from existing mechanisms. ${ }^{84}$ These existing mechanisms are the Kyoto Protocol's CDM and Joint Implementation (JI). 
The CDM has repeatedly been criticised for its poor record on human rights protection and failure to consider rights of indigenous peoples. While some CDM projects have had positive impacts on local livelihoods, ${ }^{85}$ others have been associated with outright human rights violations. For example, the Barro Blanco hydropower project in Panama was based on a faulty environmental and social impact assessment which erroneously concluded that the project would not displace people. On the contrary, the project involved forced relocations of indigenous communities, and did so without first obtaining their free, prior, and informed consent. Moreover, there was no clear resettlement plan and no structured planning of compensation measures. ${ }^{86}$ The Bujagali hydropower project in Uganda and the Olkaria IV geothermal energy project in Kenya similarly were based on flawed impact assessments and failed to at least restore the livelihoods and standards of living of the people displaced by the project. ${ }^{87}$

The CDM has been criticised for failing to screen out projects such as these, and for the fact that its procedures almost exclusively focus on how to quantify emission reductions. The only openings to consider human rights concerns in the CDM rulebook are the requirements that projects contribute to sustainable development and that stakeholders need to be consulted. ${ }^{88}$ However, the CDM Executive Board has never adopted internationally agreed criteria or procedures for assessing contributions to sustainable

85 Emily Boyd et al, 'Reforming the CDM for Sustainable Development: Lessons Learned and Policy Futures' (2009) 12 Envtl Sci \& Pol'y 820; Adam Bumpus, 'Realizing Local Development in the Carbon Commodity Chain: Political Economy, Value and Connecting Carbon Commodities at Multiple Scales' (United Nations Research Institute for Social Development 2011); Wolfgang Sterk et al, 'Further Development of the Project-Based Mechanisms in a Post-2012 Regime' (Wuppertal Institute for Climate, Environment and Energy 2009).

86 See eg Movimiento 10 de Abril, Earthjustice, CIEL, and InterAmerican Association for Environmental Defense, 'Letter to UN Special Rapporteurs on Imminent Forced Evictions of Indigenous Ngöbe Families due to Barro Blanco Dam in Panama' (18 February 2014) <https://www.ciel.org/wp-content/uploads/ 2014/11/BarroBlanco_Appeal_18Feb2014.pdf>; Obergassel et al, 'Human Rights and the Clean Development Mechanism' (n 21).

87 Jeanette Schade, 'Kenya "Olkaria IV" Case Study Report: Human Rights Analysis of the Resettlement Process' (COMCAD Working Papers 2017) < https://www.ssoar.info/ssoar/bitstream/handle/ document/51409/ssoar-2017-schade-Kenya_Olkaria_IV_Case _Study.pdf?sequence=1>; Fivas, 'Human Rights Lessons from the Bujagali Dam in Uganda' (16 June 2015), <http://fivas.org/ frontsak/human-rights-lessons-from-the-bujagali-dam-in-uganda/> accessed 15 September 2018; Obergassel et al, 'Human Rights and the Clean Development Mechanism' (n 21). development. Instead, host countries have had to define sustainable development criteria (and confirm that the project helps achieve it) and to develop procedures for local stakeholder consultations. Until recently, the limited rules on how to conduct local stakeholder consultations merely required that comments be invited, and that the project proponents provide a summary of comments received and a report on how these were taken into account. ${ }^{89}$ Notably, the CDM rules on consultation do not reference the rights of indigenous peoples or the right of free, prior, and informed consent, which is a critical protection related to projects like those approved by the CDM.

Research has shown that most host countries have only adopted non-binding guidelines, which make it easy to comply as project documentation on sustainable development and validation reports has tended to be vague and difficult to verify. Similarly, stakeholder consultation has often been rudimentary, unregulated, and badly documented. ${ }^{90}$

When presented with information about abuses related to the Bajo Aguan project, the CDM Executive Board declared that it could not consider human rights information when assessing projects. ${ }^{91}$ In November 2015, however, the CDM Executive Board decided that if stakeholders submit comments expressing human rights concerns over projects, such information should be forwarded to the respective national authorities and to 'relevant bodies within the United Nations system', that is, UN human rights bodies. ${ }^{92}$ Thus, the CDM Ex-

88 UNFCCC 'Decision 3/CMP.1, Modalities and Procedures for a Clean Development Mechanism as Defined in Article 12 of the Kyoto Protocol' UN Doc FCCC/KP/CMP/2005/8/Add.1 (30 March 2006) para 40(a)

89 ibid para $37(\mathrm{~b})$

90 Karen Holm Olsen, 'The Clean Development Mechanism's Contribution to Sustainable Development: A Review of the Literature' (2007) 84 Climatic Change 59; Obergassel et al, 'Human Rights and the Clean Development Mechanism' (n 21); Schneider (n 21); Sterk et al (n 85).

91 Annie Bird, 'Human Rights Abuses Attributed to Military Forces in the Bajo Aguan Valley in Honduras' (20 February 2013) 9, $<$ http://rightsaction.org/sites/default/files/Rpt_130220_Aguan _Final.pdf $>$ accessed 15 September 2018; Biofuel Watch, 'Palm Oil in the Aguan Valley, Honduras: CDM, Biodiesel and Murders', <http://www.biofuelwatch.org.uk/2011/palm-oil-in-the -aguan-valley-honduras-cdm-biodiesel-and-murders/> accessed 15 September 2018; Arthur Neslen, 'Carbon Credits Tarnished by Human Rights "Disgrace"' (3 October 2011), <http://www .euractiv.com/climate-environment/carbon-credits-tarnished -human-r-news-508068> accessed 15 September 2018; Jeanette Schade and Wolfgang Obergassel 'Human Rights and the Clean Development Mechanism' (2014) 27 Cambridge Rev Intl Aff 717.

92 UNFCCC, 'Meeting Report, CDM Executive Board Eighty-Seventh Meeting, Version 01.1 (No. CDM-EB87)' (2015) para 52. 
ecutive Board refused to accept the due diligence responsibility of having to consider these human rights concerns in assessing projects. At the same session, the Board also approved a concept note on improving local stakeholder consultation processes. According to the new rules, the scope of local stakeholder consultations needs to cover at least the potential direct positive and negative impacts of projects on local stakeholders. At a minimum, representatives of local stakeholders directly affected by the project and representatives of local authorities relevant to the project must be invited to participate in the project planning phase, and the project proponents need to provide evidence that the respective invitations were sent. Information should be disseminated 'in ways that are appropriate for the community that is directly affected', and include a non-technical summary of the project and its alleged positive and negative impacts, plus the means to provide comments. Project proponents need to report on how they have taken the comments received into account. ${ }^{93}$ However, these de minimis rules fail to incorporate the rights of indigenous peoples, including the right of free, prior, and informed consent.

Experience accrued with the CDM is important to understand how the SDM could and should be designed to align with human rights law and practice. Former UN Special Rapporteur John Knox has drawn attention to the need to ensure that the SDM incorporates strong social safeguards that accord with international human rights obligations. ${ }^{94}$ Similarly, the

93 UNFCCC, 'CDM Project Standard for Project Activities Version 01.0 (No. CDM-EB93-A04)' (2017) paras 89-105.

94 John Knox, 'Letter from the Special Rapporteur on Human Rights and the Environment to Climate Negotiators' (4 May 2016) $<$ http://srenvironment.org/wp-content/uploads/2016/06/Letter-to -SBSTA-UNFCCC-final.pdf> accessed 15 September 2018.

95 See OHCHR, Comments and Recommendations of $\mathrm{OHCHR}$ regarding the future UNFCCC Sustainable Development Mechanism (4 November 2016) 1 <https://www.ohchr.org/Documents/ Issues/ClimateChange/OHCHR SBSTA.pdf> accessed 15 September 2018 .

96 ibid.

97 ibid.

98 Wolfgang Obergassel and Friederike Asche, 'Shaping the Paris Mechanisms Part III - An Update on Submissions on Article 6 of the Paris Agreement' (Wuppertal Institute for Climate, Environment and Energy 2017) <https://epub.wupperinst.org/frontdoor/ index/index/docld/6987> accessed 15 September 2018.

99 Christel Cournil et al, 'Human Rights and Climate Change: EU Policy Options' (European Parliament 2012); Obergassel et al, 'Human Rights and the Clean Development Mechanism' (n 21).

100 Sterk et al (n 85); Swedish Energy Agency, 'Questionnaire Regarding Sustainable Development Co-benefits, no Harm and Stakeholder Engagement' (2015) (on file with authors).
Office of the High Commissioner for Human Rights (OHCHR) has noted that the SDM's rules, modalities, and procedures must honour the commitment to respect, promote, and consider Parties' respective obligations on human rights. ${ }^{95}$ As such, it recommended that Parties adopt an adequate social and environmental safeguard system and exercise human rights due diligence to ensure development actions do not harm communities. ${ }^{96}$ The OHCHR also recommended that the SDM should aim to finance projects that benefit those most vulnerable to the impacts of climate change. ${ }^{97}$

Therefore all projects should be required to undergo a human rights impact assessment (HRIA) with clear procedural requirements for stakeholder consultations, with only projects with positive impacts being eligible for registration. While environmental impact assessments have long been required, international financial institutions are increasingly recognising the need to conduct more comprehensive assessments that also consider human rights impacts when considering projects. Projects should be required to monitor socio-economic impacts throughout their lifetime. In addition, procedural safeguards should include complaints mechanisms, internationally, nationally, and at the project level. Finally, a procedure to de-register projects in cases where human rights violations become apparent only at the implementation stage should be created. Such a procedure would create a risk for credit buyers that projects may not deliver on their purchase agreements. Also, the creation of such a risk would prompt buyers to take the HRIA of projects into account in their purchases.

However, many countries have rejected the adoption of international standards concerning sustainability, HRIA, and stakeholder consultations. ${ }^{98}$ If no progress is achieved at the international level, individual buyer countries or coalitions of willing countries could introduce their own requirements. Three main options may be envisioned in this regard. ${ }^{99}$ First, since the transfer of emission reductions will likely require a letter of approval by the recipient country, the latter could simply decide to approve only projects that have undergone an HRIA. Second, where countries themselves are the buyers of credits, they could require projects meet certain standards, as some countries (Belgium and Sweden) have already done in the context of the CDM. ${ }^{100}$ Third, countries using emission trading systems could de- 
cide to only allow the use of credits from projects that have undergone an HRIA, thus limiting the commercial appeal of other projects - like the European Union has done in the past with projects in the forest sector.

All these scenarios, however, would not create a level playing field, as other countries may still disregard human rights when approving projects and purchasing emission reductions. This would potentially expose projects undergoing a rigorous HRIA process to a competitive disadvantage. Moreover, as carbon credits are fungible internationally, credits from projects with negative human rights impacts may enter the systems operated by countries with strong standards through the backdoor. The experience of the CDM strongly suggests that full human rights compliance should be guaranteed in the SDM modalities and procedures.

\section{Conclusion}

With increasingly strong storms, draughts, wildfires, and sea-level rise, the world is already witnessing the impacts of climate change on the enjoyment of the human rights of present and future generations. At the same time, climate change responses have already affected the rights of the most vulnerable, as seen in the context of REDD+ and CDM projects. The development of a rights-based approach to climate action is therefore critical.

In 2015, Parties decided that the implementation of the Paris Agreement would be guided by Parties' respective human rights obligations. However, this aspiration still has to be put into practice. The implementation guidelines provide the first real test of Parties' commitment to achieve greater, better, and more equitable international cooperation on climate change.

This article has suggested that there are several entry points for incorporating a human rights-based approach into the Paris Agreement's implementation guidelines, namely: guidance for NDCs, adaptation communications, the transparency framework, the global stocktake, and the rules of the Article 6 mechanism. The operationalisation of the Paris Agreement is not just about emissions reductions, but also requires the adoption of people-centred, human rightsbased climate action. In Katowice, Parties should seize the opportunities available to deliver this vision, and to comply with the human rights obligations that they already have. 